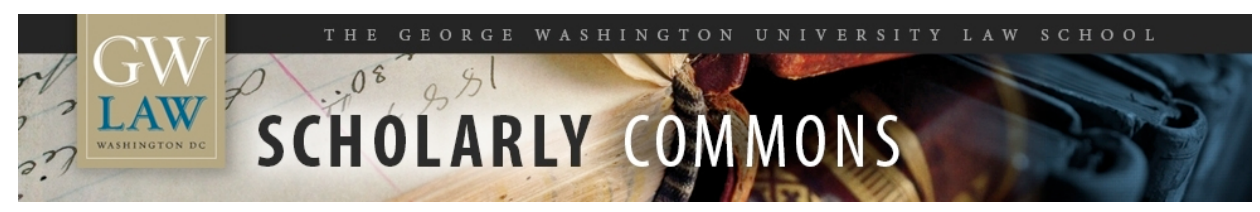

GW Law Faculty Publications \& Other Works

Faculty Scholarship

2008

\title{
Revitalizing the U.S. Compliance Power
}

Steve Charnovitz

George Washington University Law School, scharnovitz@law.gwu.edu

Follow this and additional works at: https://scholarship.law.gwu.edu/faculty_publications

Part of the Law Commons

\section{Recommended Citation}

Steve Charnovitz, Revitalizing the U.S. Compliance Power, 102 Amer. J. of Int'I L. 551 (2008)

This Article is brought to you for free and open access by the Faculty Scholarship at Scholarly Commons. It has been accepted for inclusion in GW Law Faculty Publications \& Other Works by an authorized administrator of Scholarly Commons. For more information, please contact spagel@law.gwu.edu. 
some commentators, the decision need not be read as entailing a significant reduction in the extent to which treaties will be enforced by U.S. courts. In recent years, the lower courts had, if anything, been applying a presumption against self-execution, especially for modern multilateral treaties. ${ }^{69}$ The Supreme Court stopped short of adopting any such presumption in Medellin and instead left the issue to be resolved at a retail level on a treaty-by-treaty basis. While Medellin certainly does not resolve all the issues surrounding the self-execution doctrine, and in fact is highly ambiguous about the domestic status of non-self-executing treaties, it does shed some long overdue light on a confusing area of the law. Whether one finds that light pleasing or harsh depends, of course, on other: considerations.

\section{REVITALIZING THE U.S. COMPLIANCE POWER}

\section{By Steve Chamovitz*}

Although " $[t]$ reaties are the law of the land, and a rule of decision in all courts," the president and the courts may sometimes be powerless to achieve compliance with a U.S. treaty. That was the puzzling outcome of Medellin v. Texas. ${ }^{2}$ Even though the Supreme Court declared that the United States has an international obligation to comply with the Avena judgment of the International Court of Justice (ICJ), ${ }^{3}$ the Court invalidated the president's memorandum directing Texas and other errant states to comply. ${ }^{4}$

This essay offers a commentary on Medellin and considers how the U.S. compliance power can be revitalized. Part I critiques the approach taken by the Court and shows that there was an alternative interpretation of the United Nations Charter and the U.S. Constitution. Part II considers the implications of the majority, concurring, and dissenting opinions for future U.S. implementing legislation and treaty design.

\section{HOW THE U.S. COURT COULD HAVE UPHELD THE EFFORT TO COMPLY}

By the way that it structures its analysis, the Court tilts the outcome in the direction of undermining U.S. compliance. First, the Court lays out for itself a much broader question than the true issue before it. Second, by bifurcating its analysis, ${ }^{5}$ the Court makes it harder for itself to see the legal justification for enforcing the president's determination requiring compliance.

${ }^{69}$ See Curtis A. Bradley, International Delegations, the Structural Constitution, and Non-Self-Execution, 55 STAN. L. REV. 1557, 1588 n.147 (2003) (collecting cases).

${ }^{*}$ Of the Board of Editors. The author thanks Ronald Bettauer, Susan Karamanian, and Edward Swaine for helpful comments.

${ }^{1}$ Strother v. Lucas, 37 U.S. (12 Pet.) 410, 439 (1838).

${ }^{2}$ Medellín v. Texas, 128 S.Ct. 1346 (2008).

${ }^{3}$ Id. at 1356 ("No one disputes that the Avera decision . . constitutes an international law obligation on the part of the United States."), 1367 (2008).

${ }^{4}$ George W. Bush, Memorandum for the Attorney General (Feb. 28, 2005), reprinted in John R. Crook, Con-" temporary Practice of the United States, 99 AJIL 489 (2005).

${ }^{5}$ In the Medellin opinion, following the introductory part I, part II considers the treary obligations at issue. The legal effert of the president's memorandum is considered separately in part III of the opinion. 
One of the many puzzles about the Court's decision is its use of the words "automatic" and "automatically." For example, "The question we confront here is whether the Avena judgment has automatic domestic legal effect ...." The Court uses "automatic" or "automatically" in this context thirteen times in its opinion. ${ }^{8}$ The insinuation of that word into the opinion cannot be explained as a response to the claim of the petitioner because the word does not appear in his brief. In seven of the thirteen instances, the Court uses the words "automatic" or "automatically" in a more sweeping way, that is, by considering what the implications would be "[i]f ICJ judgments were instead regarded as automatically enforceable domestic law."

Suppose rather that the Court had focused exclusively on the matter before it and posed this question: "Is the Avena judgment enforceable against Texas in view of the fact that the president has determined that the United States shall comply?" Had the Court proceeded to address this narrower question, the Justices could have avoided getting tangled in extraneous hypotheticals such as (1) the status of ICJ judgments other than Avena; (2) a refusal by the president to comply with an ICJ judgment; ${ }^{10}$ and (3) an ICJ decision judging a federal law ${ }^{11}$ to be a treaty violation. Nevertheless, because the Court posed too broad a question, its reasoning went astray.

The Court also skewed its analysis by omitting to use the president's memorandum as a prism for analyzing the enforceability of the Avena judgment. To wit, the Court considered the memorandum only after deciding that the relevant treaty provisions were non-self-executing. Once it reached its decision that the Avena judgment itself was not automatically enforceable by a court, the Court should have gone on to consider whether the president's memorandum on Avena saves Article 94(1) of the UN Charter, ${ }_{3}{ }^{12}$ in this instance, from being relegated to the status of a non-self-executing treaty obligation.

Is such an outcome--predicated on the elective act of a president-possible under the selfexecution doctrine articulated in Foster $\nu$. Neilson? ${ }^{13} \mathrm{~A}$ ready answer might be no, that a "selfexecuting" treaty needs to have that character without regard to the action or views of the executive after the treaty has been ratified. Yet Foster is hardly dispositive on that point because no executive branch view was before the Court as to the direct effect of the stipulation in the Adams-Onís Treaty of 1819 between the United States and Spain. ${ }^{14}$ Moreover, the Restatement (Third) of the Foreign Relations Law of the United States seems to suggest that executive

"128 S.Ct. at 1360 ("automatically enforceable domestic law," "automatically enforceable as domestic law," "Avena does not automatically constitute federal law ...."). In a computer search of previous Supreme Court cases adjudicating self-execution of a treaty, this author could not find any use of the word "automatic" in that context.

${ }^{7}$ Id. at 1356.

${ }^{8} \mathrm{Id}$. at 1356 (three instances), $1356 \mathrm{n} .2,1357,1359,1360$ (three instances), $1361 \mathrm{n} .9,1364,1365$ (two instances).

${ }^{9} \mathrm{Id}$. at 1360; see also id. at 1359-60, $1361 \mathrm{n} .9,1364,1365$ (two instances).

${ }^{10}$ See id. at 1360 ("Noncompliance with an ICJ judgment through exercise of the Security Council veto-always regarded as an option by the Executive and ratifying Senate during and after consideration of the U.N. Charter, Optional Protocol, and ICJ Statute-would no longer be a viable alternative.").

"Id. at 1364 ("contrary federal law" could receive "same fate" as stace law). Of course, if the Court had reversed the Texas judgment, and the case had returned to federal courts, there would have been an issue of the implications of a federal law, the Antiteriorism and Effective Death Penalty Act of 1996.

${ }^{12}$ Article 94(1) states: "Each Member of the United Nations undertakes to comply with the decision of the International Court of Justice in any case to which it is a party." UN CHARTER Art. 94(1).

${ }^{13}$ Foster v. Neilson, 27 U.S. (2 Pet.) 253 (1829).

${ }^{14}$ Carlos Manuel Vázquez, The Four Doctrines of Self-Executing Treaties, 89 AJIL 695, 702 n.35 (1995). 
action can be relevant to whether a treaty is self-executing. The Restatement says: "In general, agreements that can be readily given effect by executive or judicial bodies, federal or State, without further legislation, are deemed self-executing, unless a contrary intention is manifest." 15

To consider the meaning of Foster, one should start with the Court's holding in 1829:

Do these words ["ratified and confirmed"] act directly on the grants, so as to give validity to those not otherwise valid; or do they pledge the faith of the United States to pass acts which shall ratify and confirm them?

... Our constitution declares a treaty to be the law of the land. It is, consequently, to be regarded in courts of justice as equivalent to the act of the legislature, whenever it operates of itself without the aid of any legislative provision. But when the terms of the stipulation import a contract, when either of the parties engages to perform a particular act, the treaty addresses itself to the political, not the judicial department; and the legislature must execute the contract before it can become a rule for the Court. ${ }^{16}$

The key to (re)interpreting Foster is to appreciate that, in the 1829 litigation, the executive had not claimed that it had already acted to perform the U.S. obligations in the treaty. ${ }^{17}$ Because there was no such claim, the Foster Court considered whether the treaty stipulation "operates of itself without the aid of any legislative provision." After ruling that the treaty did not so operate, the Court reasoned that the political department addressed by the treaty was the legislature. ${ }^{18}$ The Foster Court gave no consideration to the possibility that the promised act was performable by the other political department, the executive, after which it would become a rule for the Court.

In the related Percheman case handed down four years later, the Court pointed to two potential interpretations of the treaty provision being contested: one is that the provision "stipulat [es] for some future legislative act"; ${ }^{19}$ and the other is that it acts "by force of the instrument itself." ${ }^{\prime 2} \mathrm{On}$ the basis of its Spanish text, the Court concluded that the treaty provision at issue matched the second category. ${ }^{21}$ But the opinion does not say that every treaty provision has to fit in one of those two categories.

Under this (re)reading of Foster and Percheman, the Medellin Court might have approached its task by recognizing the possibility of an intermediate category. This category would include treaty commitments that can be carried out only in the future and yet do not require legislation. Article 94(1) exemplifies that category. Immediate compliance with (or performance of ) Article 94(1) in 1945 was impossible for the United States or any country because the ICJ had not yet been constituted. U.S. compliance with Avena was not possible until the judgment was handed down in March 2004. After the president agreed to U.S. compliance in February 2005,

\footnotetext{
${ }^{15}$ RESTATEMENT (THIRD) OF THE FOREIGN RELATIONS LAW OF THE UNITED STATES $\$ 111$ reporters' n.5
(1987).

${ }^{i 6}$ Foster, 27 U.S. at 314.

${ }^{17}$ Indeed, prior federal law would have precluded such executive action. Carlos M. Vázquez, Foster v. Neilson and United States v. Percheman: Judicial Enforcement of Treaties, in INTERNATIONAL LAW STORIES 151, 167 (John E. Noyes, Laura A. Dickinson, \& Mark W. Janis eds., 2007).

${ }^{18}$ Foster, 27 U.S. at 315.

${ }^{19}$ United States v. Percheman, 32 U.S. (7 P'et.) 51, 89 (1833).

${ }^{20} \mathrm{Id}$.

${ }^{21}$ Vázquez, supra note 14 , at 701.
} 
the force of the instrument of Article 94(1) should have led to a court judgment upholding the president's action. Such a result is not foreclosed by Foster.

Unlike Foster, the Medellin case involves an ICJ judgment against the United States and what the Supreme Court calls an "unprecedented action"22 by the president. A more cautious Court might have reflected as to whether these circumstances could be distinguished from the two categories identified in Foster. A Court more respectful of international law might have started with a presumption ${ }^{23}$ in favor of upholding U.S. compliance with ICJ judgments involving U.S. treaty violations by states. Under this standard of review, the Court could have looked to Texas to explain why its interests deserve supremacy over the national interests at stake. ${ }^{24}$

The Court reached its conclusion that Article 94(1) is non-self-executing by examining the text of that provision, its context within Article 94, statements by the Truman administration to the U.S. Senate during the ratification debates of 1945 , and the text of the ICJ Statute. The Court explains that a self-executing treaty "has automatic domestic effect as federal law upon ratification." 25 This statement seems to imply that self-executing status is locked in at the time of U.S. ratification. The Court repeatedly suggests that the self-executing status of a treaty can be ascertained from material sourced in the U.S. ratification process, which, for the UN Charter, occurred in $1945 .{ }^{26}$

Nevertheless, the Court entertains a more nuanced view of treaty interpretation by stating that the determination of self-executing status may be based on factors that occur after U.S. ratification. For example, the Court recalls its case law holding that the view of the executive "is entitled to great weight," and then references the brief of the Bush administration stating that the relevant treaties in Avena do not create domestically enforceable law. ${ }^{27}$ In addition, the Court characterizes the "postratification understanding" of signatory nations and "practice among signatory nations" as legitimate interpretive factors. ${ }^{28}$ Having looked at foreign practice, the Court avers that "the lack of any basis for supposing that any other country would treat

22128 S.Ct. at 1372 (quoting Brief for the United States as Amicus Curiae Supporting Respondents at 29-30, Sanchez-Llamas v. Oregon, 126 S.Ct. 2669 (2006) (Nos. 05-51, 04-10566), 2006 WL 271823).

${ }^{23}$ Brief of International Court of Justice Experts as Amici Curiae in Support of Petitioner at 25, Medellin v. Texas, 128 S.Ct. 1346 (2008) (No. 06-984), 2007 WL 1886207 (suggesting a "presumption in favor of compliance with international obligations"); SHABTAI ROSENNE, THE INTERNATIONAL COURT OF JUSTICE 88-89 (1957) ("The duty to carry out, or comply with, such a judgment [by the ICJ] is imposed upon the courts of a State party to litigation before the International Court no less than it is incumbent upon the other organs of that State...").

${ }^{24}$ See Am. Ins. Ass'n v. Garamendi, 539 U.S. 396, 420 (2003) (suggesting that when a state acts within its traditional competerce, a conflict with national policy must be shown that would vary with the strength or the traditional importance of the state concern asserted); Lori Fisler Damrosch, The Justiciability of Paragudy's Claim of Treaty Violation, 92 AJIL 697, 703 (1998) (suggesting that the Supreme Court exercise "searching scrutiny" of states' actions affecting U.S. foreign relations that may provoke consequences for the nation as a whole); Harold G. Maier, Preemption of State Law: A Recommended Analysis, 83 AJIL 832, 838 (1989) (suggesting that preemption would follow if the adverse effects of the decision being made by the state would fall upon the entire nation and not be merely localized within the state).

25128 S.Ct. at 1356 n. 2 .

${ }^{26}$ See id. at 1356 ("and is ratified on these terms" (quoting Igartua-De La Rosa v. United States, 417 F.3d 145 , 150 (1st Cir. 2005)), 1358 ("Senate that ratified"), 1364 ("President and Senate intended"), 1366 ("determination by the President who negotiated it and the Senate that confirmed it"), 1367 ("President or Senate intended"), 1369 ("[o]nce a treaty is ratified"), ("ratified with the understanding").

${ }^{27}$ Id. at 1361. (quoting Sumitomo Shoji Am. v. Avagliano, 457 U.S. 176, 184-85 (1982)).

${ }^{28}$ Id. at 1357 . (quoting Zicherman v. Korean Air Lines, 516 U.S. 217, 226 (1996)), 1367. 
ICJ judgments as directly enforceable as a matter of their domestic law strongly suggests that the treaty should not be so viewed in our courts." 29 ' $\mathrm{n}$ particular, the Court notes that at least one local court in Morocco has held that ICJ judgments are not binding as a matter of municipal law. ${ }^{30}$

Logically, the Court cannot have it both ways. Either a U.S. treaty is immutably selfexecuting (or not) at its birth, or there is a possibility that the status of a treaty can evolve over time. If birth determines destiny, then the current voice and action of the executive branch is irrelevant. Although the decisions of foreign courts could be relevant in elucidating the intent of the original treaty makers, the reliability of such decisions would depend on the intent-based doctrine followed in the foreign court.

Consider some counterfactual situations that elucidate the Court's analytical approach: Suppose that the Bush administration had argued that Article 94(1) was self-executing. Or suppose that other countries did provide for direct enforcement of ICJ judgments. Presumably, then the Court's analysis in Medellin would have been more nuanced and might have come out the other way. ${ }^{31}$ Because the Court acknowledged postratification practice to be relevant to a treaty's status in U.S. law, one cannot read Medellin as saying that the meaning of Article 94(1) was frozen by the expectations held by the president and the Senate in 1945.

The Court does not mention the president's memorandum in part II of its opinion, the part that adjudges Article 94(1) to be non-self-executing. As a result, the Court does not even consider that the memorandum may be a relevant postratification understanding of how Article 94(1) operates. ${ }^{32} \mathrm{Had}$ the Court done so, it might have accorded greater weight to the U.S. president's determination in 2005 , pursuant to his constitutional authority as he perceived it, than to what other countries did or did not do under their respective constitutions. The proposition that the president's memorandum is probative of the self-executing status of Article 94(1) in this particular judgment was accepted in Justice Stephen G. Breyer's dissenting opinion, which found self-execution based on seven reasons taken together. One of those reasons was that "the President favors enforcement of this judgment." 33

If one reads Medellin as saying that an action by the president to give effect to an ICJ judgment cannot be a factor in ascertaining treaty self-execution, then there is a problematic inconsistency in the Court's analysis. The Medellin Court recalls its holding in the predecessor Sanchez-Llamas case that ICJ interpretations are not conclusive on U.S. courts, and then

${ }^{29}$ Id at at 1363 .

${ }^{30}$ Id. at 1363 n. 10 . The Court took issue with the portrayal of municipal implementation in an amicus brieffiled by ICJ experts, supra note 23, in particular as regards Rights of Nationals of the United States of America in Morocco (F. v. U.S.), 1952 ICJ REP. 176 (Aug. 27).

${ }^{31}$ Or perhaps it would not have done so. Most of the Courr's discussion of the postratification understanding of nations appears in part II.C of the opinion after the Court has concluded that ICJ judgments are not directly enforceable in domestic courts. Moreover, the Court says that its conclusion is "confirmed by" the postratification understanding. 128 S.Ct. at 1363. Thus, a narrower reading of the Court's opinion might be that the foreign practice discussed was only relevant to confirm the majority's conclusion and would not have been mentioned if foreign practice had called the conclusion into question. If so, that would constitute a selective and biased use of foreign legal șources.

${ }^{32}$ The Court seems to have been thrown off by the fact that the Bush administration argued that Arricle 94(1) and Avena were not self-executing. Thus, the Court did not consider possibilities for holding that Article 94(1) could be enforced by the Court as a result of the president's memorandum.

${ }^{33} 128$ S.Ct. at 1389 (Breyer, J., dissenting); see also id. at 1385 (including within the first reason that the president seeks to enforce the ICJ obligation). 
explains that "[g]iven that holding, it is difficult to see how that same structure and purpose [of the ICJ] can establish, as Medellín argues, that judgments of the ICJ nonetheless were intended to be conclusive on our courts." 34 The holding in Sanchez-Llamas was partly premised on the Court's observation that "it is doubtful that our courts should give decisive weight to the interpretation of a tribunal whose jurisdiction in this area is no longer recognized by the United States." ${ }^{35}$ What the Court was referring to was the executive branch's withdrawal in March 2005 from the Optional Protocol to the Vienna Convention on Consular Relations (VCCR). Yet that withdrawal happened decades after the United States ratified the UNCharter, which includes the ICJ Statute. So if a presidential action to withdraw U.S. agreement to give the ICJ jurisdiction is relevant to the domestic law status of an ICJ (interpretation and) judgment, it seems contradictory to overlook the relevance of the same president's action to comply with an ICJ judgment.

The Court does not question the proposition "that the President's constitutional role 'uniquely qualifies him' to resolve the sensitive foreign policy decisions that bear on compliance with an ICJ decision and 'to do so expeditiously." "'36 Yet if so, one wonders why the Court did not place the president's decision on compliance at the center of its analysis as to whether Article 94(1) is self-executing with respect to Avena. If the president is uniquely qualified to resolve sensitive policy decisions, then the Court should have shown more modesty in deciding whether to invalidate the president's resolution of Avena.

In its analysis of the status of Article 94(1), the Court draws conclusions from the UN enforcement structure, but those conclusions are misplaced. The Court avers that Article 94(1) precludes enforcement by national courts on the grounds that Article $94(2)^{37}$ provides for nonjudicial enforcement through the Security Council. ${ }^{38}$ As the dissent points out, that deduction makes no sense because Article 94(2) concerns situations where a UN member refuses to comply with an ICJ decision. ${ }^{39}$ Article 94 (2) does not give meaning to Article 94(1) when the scofflaw state agrees to comply.

The inference this author draws from the Court's opinion is that in seeking to preserve policy space for a presidential decision to withhold compliance with a treaty obligation, the Court thinks that it must deny space for a president's affirmative decision to comply. One wonders why there is not room under the U.S. Constitution for a presidential decision either to comply or not to comply. ${ }^{40}$ The Court's solicitousness about noncompliance cannot be easily reconciled with its holding that the reasons justifying the president's decision to comply are "plainly

${ }^{34} 128$ S.Ct. at 1364.

${ }^{35}$ Sanchez-Llamas v. Oregon, 126 S.Ct. 2669, 2685 (2006).

${ }^{36} 128$ S.Ct. at 1367 (quoting Brief for the United States as Amicus Curiae Supporting Petitioner at 11, 12 , Medellín v. Texas, 128 S.Ct. 1346 (2008) (No. 06-984), 2007 WL 1909462).

${ }^{37}$ Article 94(2) provides: "If any party to a case fails to perform the obligations incumbent upon it under a judg. ment rendered by the Court, the other party may have recourse to the Security Council ...." UN CHARTER Art. 94(2).

${ }^{38} 128$ S.Ct. at 1359 (ascribing an "express diplomatic--that is, nonjudicial-remedy" to drafters of Article 94); 1360 (automatic enforceability is "fatally undermined by the enforcement structure established by Article 94 "), (petitioner's construction of Article 94 "would eliminate the option of noncompliance").

${ }^{39}$ Id. at 1385 (Breyer, J., dissenting).

${ }^{40} \mathrm{Of}$ course, if Congress had legislated to forbid compliance with Avena (or to require it), that would be a different matter. 
compelling," ${ }^{21}$ or with the Court's own statement that "the ability of the political branches to determine whether and how to comply with an ICJ judgment" are "sensitive foreign policy decisions" that should not be "transferred to state and federal courts." 42

The Court seems to have overlooked the compelling U.S. interest of assuring uniformity in U.S. foreign policy. In its analysis of self-execution, the Court omits reference to an important line of cases affirming the primacy of the national government in foreign relations. In the Belmont case, the Court stated: "Plainly, the external powers of the United States are to be exercised without regard to state laws or policies. ... In respect of all international negotiations and compacts, and in respect of our foreign relations generally, state lines disappear. " ${ }^{33}$ In the Garamendi case involving executive agreements, the Court ruled that contrary state law was preempted, and explained:

There is, of course, no question that at some point an exercise of state power that touches on foreign relations must yield to the National Government's policy, given the "concern for uniformity in this country's dealings with foreign nations" that animated the Constitution's allocation of the foreign relations power to the National Government in'the first place. $^{44}$

An interpretive road not taken in Medellin was to respect these precedents on the conduct of U.S. foreign relations.

By affirming the judgment of the Texas court, the Supreme Court has unlocked the door for every state to make its own decision regarding compliance with the Avena judgment. Indeed, the states have already diverged in responding to Avena. ${ }^{45}$ The Court did not consider whether this reappearance of state lines had reached the point where an exercise of state power that touches on foreign relations should yield. The Court ought to have weighed Texas's interest in light of the plainly compelling national interest. ${ }^{46}$ Could it really be that under modern federalism, Texas has a constitutional right to flout the nation's treaty obligations regarding the treatment of aliens? ${ }^{47}$

${ }^{41} 128$ S.Ct. at 1367 . The interests noted by the Court are "ensuring the reciprocal observance" of the Vienna Convention on Consular Relations, "protecting relations with foreign governments, and demonstrating commitment to the role of international law." Id.

${ }^{42} I d$. at 1360 .

${ }^{43}$ United States v. Belmont, 301 U.S. 324, 331 (1937). Medellin differs from Belmont because the latter involved a diplomatic agreement and claim assignment pursuant to the recognition of the Soviet Union.

${ }^{44}$ Am. Ins. Ass'n v. Garamendi, 539 U.S. 396, 413 (2003) (quoting Banco Nacional de Cuba v. Sabbatino, 376 U.S. 398, 427 n.25 (1964)). The dissent in Garamendi would have upheld the California law and noted that is would "reserve foreign affairs preemption for circumstances where the President, acting under statutory or constitutional authority, has spoken clearly to the issue at hand." Id. at 442 (Ginsburg, J., dissenting). In Garamendi, the position of the executive branch had been announced by subcabinet officials, not by the president, and the executive agreements at issue had not expressly preempted state law. By concrast, in Medellin, the president announced the position of the executive branch in his memorandum and expressly addressed the state courts.

${ }^{45}$ Susan L. Karamanian, Briefly Resuscitating the Great Writ: The International Court of Justice and the U.S. Death Penalty, 69 ALBANY L. REV. 745, 758 --61 (2006); John R. Crook, Contemporary Practice of the United States, 100 AJIL 462 (2006).

${ }^{45}$ See Garamendi, 539 U.S. at 420 (suggesting thar "it would be reasonable to consider the strength of the state interest, judged by standards of traditional practice, when deciding how serious a conflict must be shown before declaring the state law preempted"). The State of 'Texas's interest was presented to the Supreme Court by the solicitor general of Texas.

${ }^{47}$ See Chy Lung v. Freeman, 92 U.S. 275, 280 (1876) (posing the question and answering no as to whether the Consticution has "done so foolish a thing as to leave it in the power of the States to pass laws whose enforcemenc 
In interpreting Article 94(1), the Court expresses agreement with the executive branch's construction of that provision as "a commitment on the part of U.N. Members to take future action through their political branches to comply with an ICJ decision." ${ }^{88}$ Yet when the Bush administration finally did so, the Court averred that the power to comply is allocated to Congress $^{49}$. rather than to the other political branch, the president. The Court does not reconcile its holding for executive branch impotence with its statement that the executive branch has the "lead role" in foreign policy. Indeed, the Court goes so far as to hold that the non-selfexecuting character of Article 94 "constrains" 51 the president's ability to comply with an ICJ judgment. The Court does not explain how Article 94(1) can have sufficient domestic effect to constrain the president if that provision lacks any domestic effect. ${ }^{52}$

Although arguments were offered that the UN Charter gave the president authority to implement ICJ judgments, the Court disagreed because "the terms of a non-self-executing treaty can become domestic law only in the same way as any other law," that is, through enactment by Congress. ${ }^{53}$ In reaching its conclusion, however, the Court did not consider the possibility that even if non-self-executing, Article 94(1) may address the executive sufficiently to clothe it with authority to preempt state law or practice. Important arguments have been made along these lines in the academy. ${ }^{54}$

Before concluding part $\mathrm{I}$, the author should respond to two potential criticisms. One is the argument that having U.S. courts enforce ICJ judgments affecting state law is problematic because too much authority is yielded to the International Court. That argument was reflected in the Supreme Court's concern that "there is nothing to prevent the ICJ from ordering state courts to annul criminal convictions and sentences, for any reason deemed sufficient by the ICJ." 55

Under the thesis put forward in this essay, however, several safeguards exist: First, an ICJ judgment can do no more than ask the United States to fulfill an international obligation it

renders the gencral government liable to just reclamations which it must answer, while it does not prohibit to the States the acts for which it is held responsible").

${ }^{48}$ : 128 . S.Ct. at 1358 (quoting Brief for the United States as Amicus Curiae Supporting Respondent at 34, Medéllín v. Dretke, 544 U.S. 916 (2005) (No. 04-5928), 2005 WL 504490). As the Court explains, the "undertakes to comply' language confirms that further action to give effect to an ICJ judgment was contemplated." Id. at 1359 n.5. But further action does not necessarily mean legislative action.

${ }^{49}$ Or it normally is. The Court admitted that it was not saying that the power of Congress to implement a treaty is exclusive and that the president would never have power pursuant to a treaty to set aside state law. Id. at $1367 \mathrm{n} .13$.

${ }^{50}$ Id. at 1367. (quoting First Nat'l City Bank v. Banco Nacional de Cuba, 406 U.S. 759, 767 (1972)); see also Jama v. Immigration \& Customs Enforcement, 543 U.S. 335, 348 (2005) (noting the "customary policy of deference to the President in matters of foreign affairs"). Jama was cited in the Medellin dissenting opinion, but not the majority opinion. 128 S.Ct. at 1389 (Breyer, J., dissenting).

${ }^{51} 128$ S.Ct. at 1371 (majority opinion).

${ }^{52}$ See id: at 1365 (stating that the UN Charter does not afford binding domestic effect).

${ }^{53}$ Id. at 1369 .

${ }^{54}$ See, e.g., Carlos Manuel Vázquez, Treaties as Law of the Land: The Supremacy Clause and the Judicial Enforcement of Treaties, available at $<\mathrm{http}: / /$ ssrn.com/abstract $=1118063>$, revised in $122 \mathrm{HARV}$. L. REV. (forthcoming
2008 ) (noting that if Article 94 were considered non-self-executing, it could reasonably be interpreted as authorizing the president to decide whether and when the nation would comply with it). Edward Swaine has raised concerns about the view that Article 94 delegates authority to the president. Edward T. Swaine, Taking Care of Treaties, 108 COLUM. L. REV: 331, 354,373-77 (2008). Instead, Swaine suggests that the president's memorandum could be
justified under the "Take Care" Clause of the U.S. Constitution. The clause states that the president "shall take Care that the Laws be faithfully executed." U.S. CONST. Art. II, $\$ 3$.

${ }^{55} 128$ S.Ct. at 1364. 
already has. ${ }^{56}$ Second, the president decides whether compliance with an ICJ judgment promotes the interest and honor of the United States. Third, in the unlikely event that the president orders compliance with an ICJ judgment that requires an unconstitutional act, then U.S. courts would not enforce it.

The other criticism is that the self-executing status of Article 94 should be a legal judgment that does not turn on the ad hoc actions of a president. Further to this point, the Medellin Court criticized an interpretive approach where a treaty obligation is "sometimes enforceable and sometimes not." ${ }^{57}$ Such criticisms of a case-by-case approach have merit. But it is unclear why the nature of a particular ICJ decision or the reparation imposed cannot be a factor in determining whether Article 94(1) is self-executing. The Supreme Court could have found that under the Constitution's Supremacy Clause, which states that treaties are the supreme law of the land, the Article 94(1) obligation in Avena is self-executing against Texas because the president had agreed to give effect to the ICJ judgment, which was itself an international law obligation of the United States.

\section{CRAFTING IMPLEMENTING LEGISLATION AND REVISING TREATIES}

An editorial in the Dallas Morning News called on Congress to "fix that loophole" created by the Supreme Court's Medellin decision. ${ }^{58}$ The decision seems clear that Congress can pass a law requiring compliance with Avena. Although it could be a law "that reaches deep into the heart of the State's police powers," is beyond Congress's authority to enact. Instead, the Court says the opposite. Several times it calls attention to the constructive role of federal implementing legislation. ${ }^{60}$ Such a law not only could remedy America's predicament in Avena, but also could put procedures in place for future ICJ decisions. ${ }^{61}$

Individual state legislatures and state courts could also take action to implement Avena. Indeed, Justice John Paul Stevens suggested in his concurring opinion that "the ICJ's decision falls on each of the States as well as the Federal Government." ${ }^{\text {"2 }}$ One could even imagine an

\footnotetext{
${ }^{56}$ Moteover, as Sean Murphy has noted, "The International Court is unlikely to issue a decision that ... is regarded by international lawyers generally as misguided, or by the global community at large as politically unacceptable." Sean D. Murphy, The United States and the International Court of fustice: Coping with Antinomies, in THE SWORD AND THE SCALES: THE UNITED STATES AND INTERNATIONAL COURTS AND TRIBUNALS (Cesate P.R. Romano ed, forthcoming 2008).

57 128 S.Ct. at 1362; see also id, at 1363 ("sometimes has the effect of domestic law and sometimes does not"). The majority opinion futther criticized the dissenting opinion by stating that its "contrary approach would assign to the courts-not the political branches-the primary role in deciding when and how international agreements will be enforced." Id. at 1363. Yet under the thesis offered here, the courts would follow the decisions made by political branches.

${ }^{58}$ Editorial, How to Treat a Treaty: Texas Murder Case Has International Ramifications, DALLAS MORNING NewS, Mar. 27, 2008, at 12A.

${ }^{59} 128$ S.Ct. at 1372 .

${ }^{60}$ See, e.g., id. at 1365 (Congress could elect to give ICJ judgment "wholesale effect"), 1366 ("Congress knows how to accord domestic effect"), 1368-69 "requirement that Congress, rather than the President, implement a non-self-executing treaty"), 1369 ("absence of congressional legislation"):

${ }^{61}$ See John H. Jackson, Status of Treaties in Domestic Legal Systems: A Policy Analysis, 86 AJIL 310, 323-29 (1992), (discussing the benefits of transformational legislation over direct application of treaties).

${ }^{62} 128$ S.C. at 1374 (Stevens, J., concurring).
} 
initiative to adopt model legislation for states. In 1962 the National Conference of Commissioners on Uniform State Laws promulgated the Uniform Foreign Money-Judgments Recognition Act, and thirty-one states have now adopted it or its 2005 update. ${ }^{63}$ As the Medellin Court notes, however, this uniform act applies only to certain types of monetary judgments and not to injunctive relief. ${ }^{64}$ Moreover, this uniform act covers judgments of foreign courts, nor judgments of international courts. Devising such a uniform act would therefore be a wholly new project.

This author hopes that the Medellin Court is correct that "Congress is up to the task of implementing non-self-executing treaties, even those involving complex commercial disputes." ${ }^{\text {"65 }}$ Such legislation could authorize the president to implement ICJ judgments or could establish an expedited procedure to gain legislative approval of compliance ${ }^{66}$ In considering such legislation concerning the ICJ, Congress could draw on its experience with statutory implementing legislation regarding judgments of the World Trade Organization (WTO) and other trade. agreements.

Under the statutory framework in the Uruguay Round Agreements Act, U.S. law declares that U.S. federal law is to prevail in the event of a conflict with W TO law. ${ }^{67}$ The Act does not assert a hierarchical relationship between state (i.e., subnational) law and W TO law, but provides that " $[\mathrm{n}]$ o State law, or the application of such a State law, may be declared invalid as to any person or circumstance. . . except in an action brought by the United States for the purpose of declaring such law or application invalid." ${ }^{68}$ Furthermore, the Act states that the "United States shall have the burden of proving" that the state law or application of that law "is inconsistent with the [WTO] agreement in question." ${ }^{69}$ That is, the Act provides that the federal government may bring suit against a state in federal court to ask that the state law be invalidated on the grounds that it is inconsistent with the WTO Agreement. These provisions imply that the rule of decision is that the WTO treaty displaces state law. ${ }^{70}$ Yet the Act does not accord equal status to judicial decisions emerging from the WTO. Rather, the Act states that when a federal court considers such a suit against a state, reports of WTO panels and the Appellate

\footnotetext{
${ }^{63}$ For the Act and updated information on it, see the Web site of the National Conference of Commissioners on Uniform State Laws, <http://www.nccusl.org/Update/>.

${ }^{64} 128$ S.Ct. at 1366-67.

${ }^{65} \mathrm{Id}$. at 1366 .

${ }^{66}$ Some precedents exist in the trade field for presidential compliance actions following international panel decisions adverse to the United States. When Congress enacted implementing legislation for the Tokyo Round multilateral trade agreements in 1979, the law authorized the president to submit legislation to Congress to amend, repeal, or enact statutes to implement requirements or recommendations under the trade agreements. The legislation was to be considered under a fast-track arrangement where an up-or-down vote was guaranteed. 19 U.S.C. \$2504(c) (2006). These provisions were never used. Another example is the Forest Resources Conservation and Shortage Relief Act, which bans the export of unprocessed timber from public lands and authorizes the president to suspend this provision in the event that a dispute panel finds that it violates a U.S. trade agreement. 16 U.S.C. $\$ 620 \mathrm{c}(\mathrm{a})$, (g) (2006).

6719 U.S.C. $\$ 3512(\mathrm{a})(1)(2006)$.

${ }^{68} 19$ U.S.C. $\$ 3512(\mathrm{~b})(2)(\mathrm{A})(2006)$.

${ }^{69} 19$ U.S.C. $\$ 3512$ (b)(2)(B)(ii) (2006).

${ }^{70}$ In Crosby v. NFTC, the Supreme Court referred to this provision and to the possibility of challenging state law "based on inconsistency with any of the 'Uruguay Round Agreements." Crosby v. Nat'l Foreign Trade Council, 530 U.S. 363,386 n.24 (2000).
} 
Body "shall not be considered as binding or otherwise accorded deference." Al Although one WTO case concerned U.S. subnational law, so far no WTO decision has held the United States to be in violation of the W TO Agreement because of state law.

Is the WTO framework a useful model for how the U.S. courts would respond to an ICJ judgment? If the procedure in the Act were used, the federal court would consider whether the state law violates the WTO Agreement. If this same implementation framework applied to Avena, the federal court would decide whether Texas law and practice violates the VCCR without according any deference to the Avena decision. In view of the recent history of VCCR cases in federal courts, using the WTO framework for ICJ cases could allow states to continue to enforce procedural default rules. So if the goal is to achieve U.S. compliance with ICJ judgments, the WTO implementing legislation is not a promising model for ICJ implementing legislation because it does not direct U.S. courts to defer to international judgments against the United States.

As regards treaty design, the Medellin Court repeatedly notes the possibility of cratting treary provisions to give the results of international adjudication domestic effect in national courts. ${ }^{72}$ By contrast, the dissenting opinion expresses skepticism about the prospects for including such domestic enforcement provisions in treaties. ${ }^{73}$ The skepticism is based on the thesis that it could be difficult to agree upon uniform language that works for all countries given the variety of national legal systems. Difficult or not, devising such language will be an important new frontier of international law in the twenty-first century.

One of many foresighted ideas of Michael Reisman, his "Draft Protocol for the Enforcement of I.C.J. Judgments" proposed in 1969, may serve as a useful starting point:

1. The undersigned States parties to this protocol, in the interests of ensuring enforcement of the judgments of the International Court of Justice, declare that

a. The enforcement of an international judgment is the obligation of all States parties to the Statute.

b. A judgment of the International Court creates rights and duties, automatically enforceable under international law and, without any incorporation, reception or such procedure, in municipal law.

c. No claim of sovereign immunity can avail against the execution, in any forum, of a judgment of the International Court of Justice.

2. Acrordingly, signatories to this protocol undertake

a. to take all general or particular measures which are necessary and appropriate for the enforcement of international judgments, in all cases in which such enforcement is sought in State organs;

${ }^{71} 19$ U.S.C. $\$ 3512$ (b)(2)(B)(i) (2006). On the other hand, the Statement of Administrative Action (SAA) explains that a court may consider the view expressed in WTO panel reports. Statement of Administrative Action, in H.R. DOC. No. 103-316, vol. 1, at 656, 675 (1994). The SAA was approved by Congress as an "authoritative expression" for any judicial proceeding. 19 U.S.C. $\$ 3512$ (d) (2006).

${ }^{72}$ 128 S.Ct. at 1369 ("If the Execucive determines that a treaty should have domestic effect of its own force, that determination may be implemented 'in mak[ing]' the treaty ...."), 1361, 1363-65.

${ }^{73}$ Id. at 1381, 1383 (Breyer, J., dissenting). 
b. to enact such internal legislation as is necessary to require domestic courts and tribunals to enforce international judgments, and rights arising thereon, solely and exclusively upon certification of the authenticity of said judgment. ${ }^{74}$

Would such a protocol be self-executing under Medellin? Given the language in paragraph 2 , the protocol would not be self-executing, despite the language in paragraph 1 (b), because paragraph 2 uses the word "undertake" and refers to the enactment of implementinglegislation if needed.

Two approaches could be used to harden the protocol's legal effect. First, the protocol could be made statutelike, but that would not work for dualist systems even though it could succeed in the United States. Second, paragraph 2 could be rewritten not as a commitment to "undertake," but as a certification that implementing authority already exists. For example: "Each signatory to this protocol agrees that before depositing its ratification, it has in place constitutional or statutory law sufficient to require enforcement of ICJ judgments by its courts." ${ }^{\text {" Th }}$ Th second option would seem to work and be consistent with Medellin.

One principle illustrated by Professor Reisman's draft protocol is that new treaty language can be designed as an optional protocol rather than as a requirement for all parties. This optional approach serves as an answer to the skepticism in the dissenting opinion about requiring all signatories to adopt "uniform" domestic law treatment. ${ }^{76}$ One example of a U.S. treaty that features nonuniform enforcement commitments is the North American Agreement on Environmental Cooperation of 1993 between Canada, Mexico, and the United States. In that Agreement, Canada alone agreed to adopt procedures that could make international panel determinations an order of a Canadian court of competent jurisdiction. ${ }^{77}$

In conclusion, the continuing U.S. delinquency in the Avena matter could have been avoided if the Supreme Court had given more respectful consideration to the Supremacy Clause. The world community is now watching to see whether Congress will act to implement the ICJ judgment. If it fails to act, that inaction would confirm the Court's skepticism about the political acceptability of giving ICJ judgments direct effect in U.S. law. This essayist hopes that Congress is up to the task of implementing the UN Charter. As Edward S. Corwin noted nearly a century ago, "[T]he United States cannot afford to multiply the occasions of its accountability before the world's tribunal by the crassest sort of negligence to provide the proper legal machinery for carrying its treaty obligations into effect." 78

${ }^{74}$ W. M. Reisman, The Enforcement of International Judgments, 63 AJIL 1, 27, app. 2 (1969).

75 See C. WILFRED JENKS, THE PROSPECTS OF INTERNATIONAL ADJUDICATION 716 (1964) (discussing how international instruments might cover implementation of international decisions).

${ }^{76} 128$ S.Ct. at 1383 (Breyer, J., dissenting).

${ }^{77}$ North American Agreement on Environmental Cooperation, Can.-Mex.-U.S., Art. 36 \& Annex 36A, Sept. 14, 1993, 32 ILM 1480, 1482 (1993). So far, no environmental dispute panel has been established; therefore, this treaty provision has not been tested.

${ }^{78}$ EDWARD S. CORWIN, NATIONAL SUPREMACY: TREATY POWER VS. STATE POWER 285-86 (1913). Corwin gives an example of a state's violation of treaty rights of aliens. Corwin's reference to tribunals refers to international arbitral tribunals agreed to by the United States. 